\title{
Luaran Penggunaan Analgesik Opiat pada Pasien Kanker
}

\author{
Outcomes of Opioid Analgesic use in Cancer Patient
}

\author{
Salma Fajar Puspita ${ }^{1}$, Zullies Ikawati ${ }^{1 *}$, Retno Muliawati ${ }^{3}$ \\ 1. Magister Farmasi Klinik, Fakultas Farmasi, Universitas Gadjah Mada \\ 2. RSUP Dr. Sardjito, Yogyakarta \\ Submitted: 24-07-2019 Revised: 13-09-2019 \\ Korespondensi : Zullies Ikawati : Email : zullies_ikawati@ugm.ac.id
}

Accepted: 26-09-2019

\begin{abstract}
ABSTRAK
Nyeri pada pasien kanker dapat menurunkan kualitas hidup pasien kanker. Pemberian obat golongan opiat merupakan lini pertama manajemen nyeri kanker, dimana fentanyl transdermal dan jenis opiat lain sering diresepkan. Penelitian ini bertujuan untuk membandingkan penurunan intensitas nyeri dan kualitas hidup pasien dengan nyeri kanker yang menggunakan fentanyl transdermal dan opiat oral. Penelitian cohort prospektif ini melibatkan pasien rawat jalan dengan nyeri kanker di Instalasi Kanker Terpadu Tulip RSUP Dr. Sardjito, Yogyakarta yang memenuhi kriteria inklusi dan eksklusi. Follow-up dilakukan melalui telefon 2 minggu setelah rekrutmen. Data intensitas nyeri dan kualitas hidup diperoleh melalui wawancara pasien dengan Numerical Rating Scale (NRS) dan kuesioner EORTC QLQ-C30. Sedangkan data demografi dan status penyakit diperoleh dari rekam medis. Luaran klinik (penurunan intensitas nyeri dan ketercapaian target nyeri) dan kualitas hidup pada kelompok fentanyl transdermal dan opiat oral disajikan secara deskriptif karena rendahnya power penelitian. Total responden yang dilibatkan adalah 111 pasien, 13 (11,71\%) pasien menggunakan fentanyl transdermal dan 98 (88,29\%) pasien menggunakan opiat oral. Pengaruh jenis opiat terhadap penurunan intensitas nyeri, ketercapaian target nyeri dan kualitas hidup tidak dapat dijustifikasi meskipun secara deskriptif fentanyl transdermal menunjukan luaran yang lebih baik daripada opiat oral. Penurunan intensitas nyeri cenderung dipengaruhi oleh usia $(p=0,000)$ dan status kesehatan global cenderung dipengaruhi oleh stadium kanker $(p=0,045)$.
\end{abstract}

Kata kunci: nyeri kanker; fentanyl transdermal; opiat; kualitas hidup; numerical rating scale

\begin{abstract}
Cancer pain might reduce the quality of life of cancer patients. Opioids are the drug of choice in cancer pain management. Fentanyl and other opioids are often prescribed. This study was aimed to compare the pain intensity reduction and quality of life of patients with cancer pain using transdermal fentanyl and other opioids. This prospective cohort study Oinvolved cancer outpatients with pain at the Tulip International Cancer Center of RSUP Dr. Sardjito, Yogyakarta fulfilling inclusion and exclusion criteria. Follow-up was carried out 2 weeks after recruitment. Pain intensity and quality of life were obtained through interview process using Numerical Rating Scale (NRS) and EORTC QLQ-C30 questionnaire. Patient demographic and disease status were obtained from medical records. Clinical outcomes (reduction in pain intensity and achievement of pain targets) and quality of life in the transdermal fentanyl and oral opioid groups were presented descriptively because of the low research power. Total respondents involved were 111 patients, $13(11.71 \%)$ patients used transdermal fentanyl and $98(88.29 \%)$ patients used oral opiates. The effect of opioid on reduction of pain intensity, achievement of pain targets and quality of life cannot be justified even though descriptively transdermal fentanyl shows better outcomes than oral opioid. The reduction of pain intensity was influenced by age $(p=0,000)$ and global health status was influenced by the stage of the cancer $(p=0.045)$.

Keywords: cancer pain; fentanyl transdermal; opioid; quality of life; numerical rating scale
\end{abstract}

\section{PENDAHULUAN}

Kanker merupakan salah satu penyakit penyumbang kematian terbesar di dunia setelah penyakit kardiovaskuler ${ }^{1}$. Selain itu, pada tahun 2016, telah dilaporkan terdapat
17,2 juta kasus disabilitas yang disebabkan oleh kanker ${ }^{2}$. Disabilitas pada pasien kanker dapat disebabkan oleh beberapa faktor, seperti fungsi kognitif, perilaku kesehatan, gangguan kesehatan, kesehatan mental, kelelahan, 
masalah tidur, kemampuan fisik, nyeri, beberapa gejala fisik, fungsi sosial dan masalah seksual ${ }^{3}$. Namun, faktor yang paling berpengaruh terhadap kualitas hidup pasien kanker adalah gejala-gejala (symptoms) yang timbul baik akibat kanker itu sendiri maupun terapi kanker. Salah satu gejala penyebab disabilitas pasien yang sangat umum terjadi pada berbagai jenis kanker adalah rasa nyeri ${ }^{4,5}$. Nyeri kanker yang tidak tertangani dengan adekuat akan mengurangi kualitas hidup pasien secara signifikan ${ }^{6,7}$. Opiat merupakan analgesik yang paling banyak digunakan oleh pasien dengan nyeri kanker8. Analgesik opiat yang beredar di Indonesia tersedia dalam berbagai jenis dan bentuk sediaan, seperti tablet, injeksi dan transdermal. Tiap jenis opiat memiliki kelebihan dan kekurangan masingmasing. Fentanyl menunjukkan efektifitas yang lebih baik untuk meredakan nyeri dibandingkan dengan morfin. Sebagian besar skor domain kualitas hidup pada pengguna fentanyl lebih baik daripada pengguna morfin'. Di samping manfaatnya, pemberian analgesik pada pasien kanker ternyata juga menimbulkan beberapa efek samping. Efek samping ini rupanya dapat menurunkan kualitas hidup pasien kanker karena mengganggu aktivitas keseharian pasien kanker. Proporsi pasien yang mengalami efek samping pun cukup banyak yaitu $70 \% 10,11$. Penelitian yang dilakukan oleh Meng dkk. ${ }^{12}$ melaporkan bahwa dibandingkan dengan opiat lainya, insidensi efek samping yang ditimbulkan oleh fentanyl lebih kecil daripada opiat lainnya. Oleh karena itu, pengukuran kualitas hidup perlu dilakukan di samping pengukuran penurunan intensitas nyeri untuk memastikan pasien kanker mendapatkan benefit yang optimal dari terapi yang diberikan. Data penelitian yang membandingkan fentanyl dengan opiat oral lainnya masih sangat kurang di Indonesia, baik terhadap luaran klinik maupun humanistik (kualitas hidup). Oleh karena itu, penelitian ini bertujuan untuk membandingkan penurunan intensitas nyeri dan kualitas hidup pasien dengan nyeri kanker yang menggunakan fentanyl transdermal dan opiat lain.

\section{METODE}

Penelitian ini bersifat noneksperimental dengan desain cohort prospektif dan melibatkan 111 pasien rawat jalan di Instalasi Kanker Terpadu Tulip (TulipICC) RSUP. Dr. Sardjito, Yogyakarta selama bulan April-Juni 2019. Berdasarkan perhitungan besar sampel, jumlah minimal subyek penelitian adalah 74 pasien pada tiap kelompok dengan tingkat kepercayaan 95\% (148 pasien). Kriteria inklusi subyek penelitian adalah penderita solid cancer yang merasakan nyeri, usia $\geq 18$ tahun, mendapatkan analgesik opiat dan bersedia menjadi subyek penelitian. Sedangkan kriteria ekslusinya adalah pasien dengan komorbid nyeri non-kanker, gangguan komunikasi, data rekam medis tidak lengkap dan lost follow-up. Penelitian ini telah mendapatkan izin dari Komisi Etik Penelitian Kedokteran dan Kesehatan, Fakultas Kedokteran, Universitas Gadjah Mada dengan nomor Ethical Clearance KE/FK/0244/EC/2019.

\section{Pengumpulan Data}

Pengambilan sampel dilakukan secara non-random dengan metode accidental sampling. Data intensitas nyeri dan kualitas hidup diperoleh melalui wawancara kepada pasien saat menerima obat di Apotek TulipICC dengan didahului menandatangani informed consent. Sedangkan data demografi dan status penyakit diperoleh dari rekam medis.

\section{Alat Ukur}

Intesitas Nyeri

Numerical Rating Scale (NRS) merupakan instrumen pengukuran intensitas nyeri yang terdiri atas angka 0-10 dengan jarak antar skala adalah 1 . Skala 0 bermakna tidak nyeri sama sekali sedangkan skala 10 bermakna nyeri yang teramat hebat. Pasien diminta menunjukkan skala yang 
paling merepresentasikan intensitas nyeri yang dirasakan sekarang.

Kualitas Hidup

European Organization for Research and Treatment of Cancer Quality of Life Questionnaire-C30 (EORTC QLQ-C30) adalah kuesioner khusus untuk pasien kanker. keusioner ini sudah tersedia dalam bahasa Indonesia dan divalidasi oleh Perwitasari dkk. ${ }^{13}$ pada berbagai jenis kanker. Kuesioner ini terdiri atas 30 pertanyaan. Skor tiap item dalam 3 domain utama diukur berdasarkan pengukuran yang dilakukan oleh Fayers dkk. ${ }^{14}$ Penilaian kualitas hidup berdasarkan kuesioner ini mencakup angka 1 sampai 4 untuk domain fungsional dan gejala dan angka 1 sampai 7 untuk domain status kesehatan global. Pada domain fungsional dan gejala, nilai 1 bermakna tidak, nilai 2 bermakna sedikit, nilai 3 bermakna sering dan nilai 4 bermakna sangat sering. Pada skala status kesehatan global, semakin mendekati angka 7 maka kualitas hidup semakin baik, begitu pula sebaliknya. Nilai tiap item pertanyaan dalam 1 domain dijumlahkan untuk mendapatkan skor domain. Perubahan skor domain dilakukan dengan mengurangkan skor saat follow-up dari skor saat rekrutmen. Nilai positif pada domain status kesehatan global dan fungsional bermakna perbaikan kondisi pasien, sedangkan nilai positif pada domain gejala bermakna perbukuran gejala pasien.

\section{Analisis Statistik}

Perbedaan penurunan intensitas nyeri, perubahan skor domain status kesehatan global dan domain fungsional kelompok fentanyl transdermal dan opiat oral disajikan secara deskriptif karena keterbatasan power penelitian. Analisis statistik hanya dilakukan untuk mengetahui pengaruh faktor demografi subyek maupun status penyakit terhadap luaran penelitian. Piranti lunak yang digunakan adalah SPSS versi 23 dengan kebermaknaan $p<0,05$.
HASIL DAN PEMBAHASAN Demografi dan Status Penyakit Pasien

Jumlah pasien yang memenuhi kriteria inklusi adalah 133 pasien. Setelah 2 minggu pemakaian analgesik, 22 pasien dieksklusi dari penelitian karena lost follow-up, 1 pasien dari kelompok fentanyl transdermal dan 21 pasien dari kelompok opiat lain. Pada akhir penelitian, jumlah pasien pada kelompok fentanyl transdermal adalah 13 pasien dan 98 pasien pada opiat lain. Oleh karena itu, power penelitian hanya sebesar 31,34\%. Karakteristik pasien pada kedua kelompok dijabarkan pada tabel I.

Berdasarkan tabel I, secara umum karakterteristik pasien dari segi demografi dan status penyakit tidak berbeda signifikan. Hanya saja, intensitas nyeri pada kelompok fentanyl transdermal lebih tinggi daripada kelompok opiat lainnya. Hal ini ditunjukkan dengan perbedaan proporsi pasien dengan intensitas ringan dan nyeri sedang hingga berat pada kedua kelompok. Jika dilihat secara keseluruhan, proporsi pasien dengan intensitas ringan adalah sebesar 18,92\% $(n=21)$, sedangkan pasien dengan intensitas nyeri sedang hingga berat adalah 81,08\% ( $n=90)$. Hal ini sejalan dengan penelitian yang dilakukan Ho dkk. ${ }^{10}$ mengenai manajemen nyeri pada pasien pasien kanker di 10 negara asia, termasuk Indonesia. Penelitian tersebut melaporkan bahwa proporsi pasien kanker dengan nyeri sedang hingga berat adalah sebesar $86,2 \%$.

Dalam penelitian kali ini, 84,68\% subyek ( $\mathrm{n}=94)$ mendapat morfin, $11,71 \%$ subyek ( $n=13)$ mendapat fentanyl, 2,7\% subyek $(\mathrm{n}=3)$ mendapat tramadol dan $0,9 \%$ subyek $(n=1)$ mendapat kodein. Proporsi ini sejalan dengan penelitian Thinh $\mathrm{dkk} .{ }^{8}$ yang melaporkan bahwa morfin merupakan analgesik opiat yang paling banyak diresepkan pada pasien kanker, diikut dengan fentanyl. Gambaran jenis dan dosis analgesik pada penelitian ini dijabarkan dalam tabel II berikut. 
Tabel I. Gambaran Demografi dan Status Penyakit Subyek Penelitian

\begin{tabular}{|c|c|c|c|}
\hline Karakteristik pasien & Opiat oral, n (\%) & Transdermal fentanyl, n (\%) & Nilai $p$. \\
\hline \multicolumn{4}{|l|}{ Usia } \\
\hline$<60$ tahun & $60(61,22 \%)$ & $9(69,23 \%)$ & 0,763 \\
\hline$\geq 60$ tahun & $38(38,78 \%)$ & $4(30,77 \%)$ & \\
\hline \multicolumn{4}{|l|}{ Jenis Kelamin } \\
\hline Laki-laki & $38(38,78 \%)$ & $5(38,46 \%)$ & 0,983 \\
\hline Perempuan & $60(61,22 \%)$ & $8(61,54 \%)$ & \\
\hline \multicolumn{4}{|l|}{ Index Massa Tubuh } \\
\hline Under weight & $24(24,49 \%)$ & $6(46,15 \%)$ & 0,162 \\
\hline Normal weight & $64(65,31 \%)$ & $6(46,15 \%)$ & \\
\hline Overweight & $10(10,20 \%)$ & $1(7,70 \%)$ & \\
\hline \multicolumn{4}{|l|}{ Lokasi kanker } \\
\hline Payudara & $28(28,57 \%)$ & $2(15,38 \%)$ & 0,304 \\
\hline Kolorektal & $16(16,33 \%)$ & $3(23,08 \%)$ & \\
\hline Kepala dan leher & $25(25,51 \%)$ & $2(15,38 \%)$ & \\
\hline Lain-lain & $29(29,59 \%)$ & $6(46,16 \%)$ & \\
\hline \multicolumn{4}{|l|}{ Stadium } \\
\hline II & $21(28,77 \%)$ & $1(9,09 \%)$ & 0,162 \\
\hline III & $24(32,88 \%)$ & $2(18,18 \%)$ & \\
\hline IV & $28(38,36 \%)$ & $8(72,73 \%)$ & \\
\hline \multicolumn{4}{|l|}{ Status metastasis } \\
\hline Metastasis & $28(38,89 \%)$ & $8(72,73 \%)$ & 0,050 \\
\hline Tidak metastasis & $44(61,11 \%)$ & $3(27,27 \%)$ & \\
\hline \multicolumn{4}{|c|}{ Sedang menjalani kemoterapi } \\
\hline $\mathrm{Ya}$ & $52(53,06 \%)$ & $8(61,54 \%)$ & 0,564 \\
\hline Tidak & $46(46,94 \%)$ & $5(38,46 \%)$ & \\
\hline \multicolumn{4}{|l|}{ Durasi sakit } \\
\hline$<1$ tahun & $28(28,57 \%)$ & $5(38,46 \%)$ & 0,523 \\
\hline$\geq 1$ tahun & $70(71,43 \%)$ & $8(61,54 \%)$ & \\
\hline \multicolumn{4}{|l|}{ Klasifikasi Nyeri } \\
\hline Ringan & $21(21,43 \%)$ & $0(0 \%)$ & $0,003^{*}$ \\
\hline Sedang & $36(36,73 \%)$ & $1(7,69 \%)$ & \\
\hline Berat & $41(41,84 \%)$ & $12(92,31 \%)$ & \\
\hline
\end{tabular}

*berbeda singnifikan secara statistik (Uji Fisher's exact test, kebermaknaan $p<0,05$ )

\section{Perbandingan Luaran Klinik}

Penurunan intensitas nyeri diperoleh dengan mengurangkan intensitas nyeri saat rekrutmen follow-up dari intensitas nyeri saat rekrutmen. Penurunan intensitas nyeri kelompok fentanyl transdermal dan opiat oral ditunjukkan dalam tabel III.

Berdasarkan tabel III, terdapat penurunan intensitas nyeri pada kedua kelompok, hal ini bermakna bahwa baik fentanyl transdermal maupun opiat lainnya dapat menurunkan intensitas nyeri pada pasien kanker dalam jangka waktu 2 minggu. Namun, penurunan intensitas nyeri pada subyek yang menggunakan fentanyl transdermal lebih besar daripada penurunan intensitas nyeri pada subyek yang menggunakan opiat oral lainnya. Penurunan intensitas nyeri kedua kelompok ini sejalan dengan penelitian yang dilakukan oleh Wang dkk. ${ }^{16}$ yang menyatakan bahwa tidak terdapat perbedaan efektifitas yang signifikan secara 
Tabel II. Gambaran Jenis Analgesik Opiat, Dosis dalam 24 jam dan Dosis ekuinalgesik ${ }^{15}$

\begin{tabular}{lccc}
\hline Jenis analgesik opiat & Dosis dalam 24 jam & Dosis ekuinalgesik & n (\%) \\
\hline Kodein & $20 \mathrm{mg}$ & $3 \mathrm{mg}$ & $1(0,90 \%)$ \\
Tramadol & $50 \mathrm{mg}$ & $30 \mathrm{mg}$ & $1(0,90 \%)$ \\
& $75 \mathrm{mg}$ & $45 \mathrm{mg}$ & $1(0,90 \%)$ \\
\multirow{3}{*}{ Morfin } & $112,5 \mathrm{mg}$ & $67,5 \mathrm{mg}$ & $1(0,90 \%)$ \\
& $10 \mathrm{mg}$ & $10 \mathrm{mg}$ & $1(0,90 \%)$ \\
& $20 \mathrm{mg}$ & $20 \mathrm{mg}$ & $84(75,68 \%)$ \\
Fentanyl transdermal & $30 \mathrm{mg}$ & $30 \mathrm{mg}$ & $7(6,31 \%)$ \\
& $45 \mathrm{mg}$ & $45 \mathrm{mg}$ & $2(1,80 \%)$ \\
& $12,5 \mu \mathrm{g} / \mathrm{jam}$ & $30 \mathrm{mg}$ & $5(4,50 \%)$ \\
& $25 \mu \mathrm{g} / \mathrm{jam}$ & $60 \mathrm{mg}$ & $7(6,31 \%)$ \\
& $50 \mu \mathrm{g} / \mathrm{jam}$ & $120 \mathrm{mg}$ & $1(0,90 \%)$ \\
\hline
\end{tabular}

Tabel III. Perbandingan Penurunan Intensitas Nyeri Fentanyl Transedermal dan Opiat Oral

\begin{tabular}{lcccc}
\hline \multicolumn{1}{c}{ Jenis analgesik } & Sebelum \pm SD & Sesudah \pm SD & Selisih \pm SD & \% penurunan \\
\hline Opiat oral & $5,99 \pm 2,56$ & $4,53 \pm 2,84$ & $1,46 \pm 2,65$ & $20,71 \pm 53,28$ \\
Fentanyl transdermal & $8,31 \pm 1,55$ & $5,38 \pm 2,57$ & $2,92 \pm 2,63$ & $34,00 \pm 30,33$ \\
\hline
\end{tabular}

Tabel IV. Perbandingan Ketercapaian Target Nyeri Kelompok Fentanyl Transdermal dan Opiat Oral

\begin{tabular}{lcc}
\hline Jenis analgesik & Tidak tercapai, $\mathbf{n}(\mathbf{\%})$ & Tercapai, $\mathbf{n}(\mathbf{\%})$ \\
\hline Opiat oral & $66(67,45 \%)$ & $32(32,65 \%)$ \\
fentanyl transdermal & $7(53,85 \%)$ & $6(46,15 \%)$ \\
\hline
\end{tabular}

statistik antara kedua sediaan $(R R=1,00,95 \%$ CI 0,97-1,03, p>0,05).

Analisis pengaruh faktor demografi dan status penyakit terhadap penurunan intensitas nyeri menunjukkan bahwa hanya faktor yang usia yang berpengaruh terhadap luaran ini. Penurunan intensitas nyeri kelompok usia $\geq 60$ tahun $(1,79 \pm 2,48)$ lebih besar daripada kelompok usia $<60$ tahun $(1,54 \pm 2,81)(p=0,000)$. Hal ini sesuai dengan penelitian sebelumnya yang dilakukan oleh Yen dkk.17. Perbedaan penurunan intenistas nyeri ini berkaitan dengan perubahan farmakonetik dan farmakodinamik opiat pada pasien geriatri ${ }^{18}$. Fungsi ginjal akan berkurang seiring dengan bertambahnya usia. Hal ini menyebabkan penurunan ekskresi opiat sehingga terjadi peningkatan kadar opiat dalam tubuh. Perubahan sensitifitas reseptor opiat juga terjadi pada populasi geriatri sehingga efek yang ditimbulkan akan lebih besar daripada populasi dewasa meskipun menggunakan dosis yang sama ${ }^{19}$.

Meskipun kedua jenis opiat menunjukkan penurunan intensitas nyeri, perlu diteliti juga apakah penurunan intensitas nyeri tersebut mencapai target atau tidak. Ketercapaian target nyeri ini berkaitan dengan implikasi kebermaknaan penurunan intenistas nyeri secara klinik. Analisis ketercapaian target nyeri pasien kanker perlu dilakukan karena penurunan nyeri yang tidak mencapai target berkaitan dengan gangguan fungsional pada kualitas hidup pasien ${ }^{20}$. Berdasarkan Carlson $\mathrm{dkk}^{21}$ dan Bandieri dkk.22, target nyeri dinyatakan tercapai atau bermakna secara klinik jika penurunan intensitas nyeri bernilai $\geq 50 \%$. Proporsi Ketercapaian target nyeri kedua kelompok opiat disajikan dalam tabel IV. 
Tabel IV. Perbandingan Penurunan Intensitas Nyeri Fentanyl Transedermal dan Opiat Oral pada Kelompok Nyeri Intensitas Sedang hingga Berat

\begin{tabular}{lcccc}
\hline \multicolumn{1}{c}{ Jenis analgesik } & Sebelum \pm SD & Sesudah \pm SD & Selisih \pm SD & \% penurunan \\
\hline Opiat oral & $6,96 \pm 1,95$ & $5,13 \pm 2,62$ & $1,83 \pm 2,60$ & $24,63 \pm 37,39$ \\
fentanyl transdermal & $8,31 \pm 1,55$ & $5,38 \pm 2,57$ & $2,92 \pm 2,63$ & $34,00 \pm 30,33$ \\
\hline
\end{tabular}

Tabel V. Perbandingan Ketercapaian Target Nyeri Kelompok Fentanyl Transdermal dan Opiat Oral

\begin{tabular}{lcc}
\hline Jenis analgesik & Tidak tercapai, n(\%) & Tercapai, $\mathbf{n}(\mathbf{\%})$ \\
\hline Opiat oral & $55(71,40 \%)$ & $32(28,60 \%)$ \\
fentanyl transdermal & $7(53,80 \%)$ & $6(46,20 \%)$ \\
\hline
\end{tabular}

Berdasarkan tabel IV, proporsi subyek dengan target nyeri tercapai pada kedua kelompok kurang dari proporsi subyek dengan target nyeri tidak tercapai. Meskipun demikian proporsi pasien dengan target nyeri tercapai pada kelompok fentanyl transdermal lebih besar daripada kelompok opiat oral. Penelitian ini tidak sejalan dengan penelitian Ahmedzai dan Brook $^{23}$ yang menyatakan bahwa proporsi pasien dengan target nyeri tercapai lebih besar daripada proporsi pasien dengan target nyeri tidak tercapai. Selain itu, penelitian Ahmedzai dan Brook tersebut juga menunjukkan bahwa proporsi pasien dengan target nyeri tercapai pada kelompok opiat oral lebih besar daripada kelompok fentanyl transdermal. Namun, penelitian yang dilakukan Ahmedzai Brooks tidak mendefinisikan ketercapaian target nyeri secara jelas. Perbedaan penelitian diduga terjadi karena adanya penggunaan rescue dose immediate release morfin pada penelitian yang dilakukan oleh Ahmedzai dan Brook ${ }^{23}$. Berdasarkan penelitian ini, rescue dose diberikan kepada kelompok fentanyl transdermal selama 53,9\% dari hari penelitian. Sedangkan pada kelompok opiat oral, rescue dose diberikan selama $41,5 \%$ dari hari penelitian. Rescue dose ini diberikan untuk mengatasi breakthrough pain, yang merupakan eksaserbasi nyeri yang berlangsung sementara pada pasien dengan nyeri persisten yang stabil 24. Meskipun pada penelitian Devulder dkk. ${ }^{25}$ pemberian rescue dose terhadap pasien dengan nyeri non-kanker tidak berpengaruh signifikan secara statisik terhadap efektifitas analgesik long acting, namun masih terdapat bias pada studi Devulder dkk. ini akibat ketidakseimbangan kualitas sumber literatur antara kelompok dengan rescue dose dan tanpa rescue dose. Tidak ditemukan pengaruh antara faktor demugrafi maupun status penyakit terhadap ketercapaian target nyeri.

Penurunan intensitas nyeri dan ketercapaian target nyeri kedua kelompok yang tidak berbeda dapat disebabkan oleh perbedaan baseline nyeri kedua kelompok. Seluruh subyek pada kelompok fentanyl transdermal menderita nyeri dengan intensitas sedang hingga berat, sedangkan subyek pada kelompok opiat oral menderita nyeri dengan intensitas ringan hingga berat. Oleh karena itu, analisis subgrup dilakukan pada kelompok intensitas nyeri sedang hingga berat. Perbandingan penurunan intensitas nyeri kelompok fentanyl transdermal dan opiat oral ditunjukkan pada tabel IV.

Berdasarkan tabel IV, terlihat bahwa penurunan intensitas nyeri pada kelompok fentanyl transdermal lebih besar daripada opiat oral. Hal ini bermakna tidak terdapat perbedaan efektivitas fentanyl transdermal dengan opiat oral lainnya dalam meredakan nyeri pada psien dengan nyeri sedang hingga berat. Penelitian ini sejalan dengan penelitian yang dilakukan oleh Yang dkk.26. Analisis pengaruh jenis analgesik terhadap ketercapaian target nyeri pada pasien dengan nyeri sedang hingga berat dijabarkan dalam tabel V. 
Tabel VI. Perbandingan Kualitas Hidup Kelompok Fentanyl Transdermal dan Opiat Oral

\begin{tabular}{lccc}
\hline \multicolumn{1}{c}{ Jenis analgesik opiat } & Sebelum \pm SD & Sesudah \pm SD & Selisih \pm SD \\
\hline Domain status kesehatan global & & & \\
$\quad$ Opiat oral & $64,54 \pm 20,32$ & $67,69 \pm 23,27$ & $3,15 \pm 23,34$ \\
$\quad$ Fentanyl transdermal & $50,00 \pm 15,96$ & $59,61 \pm 22,27$ & $9,62 \pm 16,61^{*}$ \\
Domain fungsional & & & \\
$\quad$ Opiat oral & $372,28 \pm 79,52$ & $373,60 \pm 84,59$ & $1,31 \pm 67,88$ \\
$\quad$ Fentanyl transdermal & $285,38 \pm 119,56$ & $288,20 \pm 101,95$ & $2,82 \pm 68,80^{*}$ \\
Domain gejala & & & \\
$\quad$ Opiat oral & $229,97 \pm 132,58$ & $204,31 \pm 134,01$ & $-25,67 \pm 111,36$ \\
$\quad$ Fentanyl transdermal & $387,18 \pm 15708$ & $291,45 \pm 146,40$ & $-95,73 \pm 175,76^{*}$ \\
\hline
\end{tabular}

*Perubahan skor yang lebih baik

Berdasarkan tabel $\mathrm{V}$ tersebut, proporsi subyek dengan target nyeri tercapai kurang dari subyek dengan target nyeri tidak tercapai pada kelompok opiat oral. Hal yang sama terjadi pada kelompok fentanyl transdermal. Proporsi subyek dengan target nyeri tercapai pada kelompok fentanyl transdermal lebih besar daripada subyek pada kelompok opiat oral. Penelitian yang dilakukan oleh Yang dkk. ${ }^{22}$ menunjukkan bahwa proporsi pasien dengan penurunan intensitas nyeri $\geq 50 \%$ pada kelompok fentanyl transdermal adalah 86,60\% dan $88,31 \%$ pada kelompok opiat lain. Meskipun demikian, proporsi tersebut tidak berbeda signifikan secara statistik $(R R=1.13$, $95 \%$ CI $(0.92,1.38), p=0.230)$.

\section{Perbandingan Kualitas Hidup}

Kualitas hidup yang berkaitan dengan kesehatan (Health Related Quality of Life/HRQoL) menggambarkan pandangan individu pada kebahagiaan dan kepuasan terhadap kehidupan yang mempengaruhi kesehatan individu. Hasil analisis perbedaan perubahan skor 3 domain utama kualitas hiudp pada kelompok transdermal fentanyl dan opiat oral dijabarkan dalam tabel VI berikut.

Berdasarkan tabel VI, pemberian kedua jenis opiat menunjukkan perbaikan pada ketiga domain utama. Kelompok opiat transdermal menunjukkan perbaikan skor yang lebih besar daripada kelompok opiat oral. Domain status kesehatan global menggambarkan persepsi pasien terhadap kualitas hidup dan status kesehatannya secara umum. Pada penelitian sebelumnya, pasien dengan fentanyl transdermal mengalami penurunan status kesehatan global, sedangkan pada pasien dengan opiat oral tidak terdapat perubahan skor status kesehatan global, namun perbedaan ini juga tidak signifikan secara statistik ${ }^{23}$.

Domain status kesehatan global cenderung dipengaruhi oleh stadium kanker daripada penggunaan analgesik opiat. Perubahan skor domain status kesehatan global pada stadium II adalah 12,50 $\pm 18,32$, stadium III adalah 1,92 $\pm 22,40$ dan stadium IV adalah $-2,55 \pm 25,65(p=0,045)$. Analisis Post-hoc menunjukkan bahwa terdapaat perbedaan yang signifikan secara statistik antara stadium II dengan III $(p=0,045)$ dan stadium II dengan IV $(p=0,016)$, sedangkan antara stadium III dan IV tidak terdapat perbedaan yang signifikan $(p=0,524)$. Penelitian sebelumnya menunjukkan pola yang sama dengan hasil penelitian ini. Pasien dengan stadium awal kanker menunjukkan status kesehatan global yang lebih baik dan signifikan secara statistik $(p=0,000){ }^{27}$. Jika dilihat dari nilai selisih skor pada tiap stadium, nilai positif berada pada stadium II dan III sedangkan nilai negatif berada pada staidum IV. Nilai positif bermakna terdapat perbaikan status kesehatan global. Hal ini menunjukkan pemberian analgesik terhadap pasien dengan nyeri kanker pada stadium II dan III dapat memperbaiki status kesehatan globalnya. Sedangkan nilai negatif bermakna tidak 
terjadi perbaikan status kesehatan global. Hal ini menunjukkan bahwa pemberian analgesik tidak dapat memperbaiki status kesehatan global pada pasien dengan stadium IV.

Hasil analisis terhadap domain fungsional pada penelitian ini berbeda dengan penelitian yang dilakukan oleh Payne dkk. ${ }^{28}$. Penelitian tersebut menyebutkan bahwa skor domain fungsional pada opiat oral lebih besar daripada fentanyl transdermal dan perbedaan tersebut berbeda signifikan secara statistik $(p<0,001)$. Perbedaan ini diduga dapat terjadi akibat perbedaan kuesioner yang digunakan. Kuesioner yang digunakan pada penelitian Payne dkk. ${ }^{28}$ adalah Functional Assessment of Cancer Therapy-General (FACT-G) dimana domain fungsional merupakan gabungan 3 subdomain yaitu sosial, emosional dan funsional. Sedangkan pada penelitian kali ini, kuesioner yang digunakan adalah EORTC QLQ-C30 dimana domain fungsional terdiri atas subdomain fungsi fisik, fungsi peran, fungsi emosi, fungsi sosial dan fungsi emosional.

Domain gejala menggambarkan kondisi gejala yang dirasakan oleh pasien secara keseluruhan. Domain ini terdiri atas beberapa subdomain yang berkaitan dengan penggunanaan analgesik opiat yaitu mual dan muntah, nyeri, sesak nafas, insomnia dan konstipasi. Hasil penelitian ini menunjukkan bahwa gejala yang dialami pengguna opiat oral lebih besar daripada pengguna fentanyl transdermal. Namun, pengaruh faktor jenis kemoterapi perlu diteliti lebih lanjut untuk memastikan gejala yang terjadi hanya dipengaruhi opiat. Penelitian sebelumnya yang dilakukan oleh Payne dkk. ${ }^{28}$ menunjukkan bahwa skor domain gejala pada kelompok fentanyl transdermal dan opiat oral tidak berbeda signifikan secara statistik $(p=0,220)$.

Keterbatasan penelitian ini adalah jumlah sampel yang tidak seimbang pada kedua kelompok sehingga menyebabkan power penelitian kurang dari $80 \%$. Kurangnya power penelitian ini menyebabkan pengaruh jenis opiat terhadap luaran klinik dan kualitas hidup tidak dapat dijustifikasi. Oleh karena itu, perlu dilakukan penelitian lebih lanjut dengan jumlah subyek yang memadahi. Penelitian ini tidak menganalisis riwayat penggunaan analgesik sebelumnya, pasien yang sudah pernah menggunakan opiat tentunya akan menghasilkan luaran klinik yang berbeda dengan pasien yang belum pernah menggunakan opiat. Hal ini berkaitan dengan adanya toleransi terhadap analgesik yang sudah pernah digunakan sebelumnya ${ }^{29}$. Selain itu, komplikasi penggunaan opioid pada pengguna jangka panjang berupa Opioidinduced Hyperalgesia (OIH) juga dapat berpengaruh terhadap luaran penelitian ${ }^{30}$. Faktor lain yang dapat mempengaruhi luaran klinik adalah kepatuhan pasien. Pasien yang menggunakan fentanyl transdermal cenderung patuh pada regimen pengobatan daripada pasien dengan opiat oral. Sedangkan faktor lain yang dapat berpengaruh pada kualitas hidup adalah kondisi sosio demografi. Namun pada penelitian ini, kepatuhan dan kondisi sosiodemografi tidak dianalisis.

\section{KESIMPULAN}

Pada penelitian ini, pengaruh jenis opiat terhadap penurunan intensitas nyeri, ketercapaian target nyeri dan perubahan kualitas hidup pada psien kanker tidak dapat dijustifikasi. Namun, terdapat faktor demografi dan status penyakit yang berpengaruh pada luaran penelitian. Pada penelitian ini, usia berpengaruh terhadap penurunan intensitas nyeri dan stadium kanker berpengaruh pada domain status kesehatan global dari kualitas hidup.

\section{DAFTAR PUSTAKA}

1. Wang $\mathrm{H}$, Naghavi M, Allen $\mathrm{C}$, et al., Global, regional, and national life expectancy, all-cause mortality, and cause-specific mortality for 249 causes of death, 1980-2015: a systematic analysis for the Global Burden of Disease Study 2015. Lancet. 2016.

2. Vos T, Abajobir AA, Abbafati C, et al., Global, regional, and national incidence, prevalence, and years lived 
with disability for 328 diseases and injuries for 195 countries, 1990-2016: A systematic analysis for the Global Burden of Disease Study 2016. Lancet. 2017.

3. van Leeuwen M, Husson O, Alberti P, et al., Understanding the quality of life (QOL) issues in survivors of cancer: towards the development of an EORTC QOL cancer survivorship questionnaire. Health Qual Life Outcomes. 2018;16(1):114.

4. Damodar G, Gopinath S, Vijayakumar S, Rao AY. Reasons for low quality of life in South Indian cancer patient population: a prospective observational study. Indian J Pharm Sci. 2014;76(1):2-9. http://www.ncbi.nlm.nih.gov/pubmed/ 24799733. Accessed July 23, 2019.

5. Wang H-L, Kroenke K, Wu J, Tu W, Theobald D, Rawl SM. Cancer-related pain and disability: a longitudinal study. J Pain Symptom Manage. 2011;42(6):813-821.

6. Temel JS, Blinderman CD, Jacobsen J, Pirl WF, Billings JA, Lynch TJ. Early Palliative Care for Patients with Metastatic Non-Small-Cell Lung Cancer. N Engl J Med. 2010.

7. Hjermstad MJ, Kaasa S, Caraceni A, et al., Characteristics of breakthrough cancer pain and its influence on quality of life in an international cohort of patients with cancer. BMJ Support Palliat Care. 2016;6(3):344-352.

8. Thinh DHQ, Sriraj W, Mansor M, et al., Analgesic Prescription Patterns and Pain Outcomes in Southeast Asia: Findings From the Analgesic Treatment of Cancer Pain in Southeast Asia Study. J Glob Oncol. 2018.

9. Koyyalagunta D, Bruera E, Solanki DR, et al., A systematic review of randomized trials on the effectiveness of opioids for cancer pain. Pain Physician. 2012.

10. Ho KY, Ahn JS, Calimag MM, et al., Inadequate treatment practices for pain relief and adverse event management in cancer patients across 10 countries/regions in Asia: a call for greater efforts to improve standards for patient care. Asia Pac J Clin Oncol. 2018;14(3):159-166.

11. Sloot S, Boland J, Snowden JA, et al., Side effects of analgesia may significantly reduce quality of life in symptomatic multiple myeloma: a cross-sectional prevalence study. Support Care Cancer. 2015.

12. Meng $\mathrm{Z}, \mathrm{Yu} \mathrm{J}$, Acuff $\mathrm{M}$, et al., Tolerability of Opioid Analgesia for Chronic Pain: A Network MetaAnalysis. Sci Rep. 2017;7(1):1995. doi:10.1038/s41598-017-02209-x

13. Perwitasari DA, Atthobari J, Dwiprahasto I, et al., Translation and validation of EORTC QLQ-C30 into Indonesian version for cancer patients in Indonesia. Jpn J Clin Oncol. 2011.

14. Fayers P, Aaronson NK, Bjordal K, Groenvold M, Curran D, Bottomley A. EORTC QLQ-C30 Scoring Manual. European Organisation for Research and Treatment of Cancer; 2001.

15. Swarm R, Abernethy P, Anghelescu DL, et al., Adult Cancer Pain. J Natl Compr Cancer Netw. 2010;8(9):1046-1086.

16. Wang D-D, Ma T-T, Zhu H-D, Peng CB. Transdermal fentanyl for cancer pain: Trial sequential analysis of 3406 patients from 35 randomized controlled trials. J Cancer Res Ther. 2018;14(Supplement):S14-S21.

17. Yen CR, Tsou MY, Mandell MS, et al., An analysis of patient variables that influence intravenous patientcontrolled analgesic use of morphine with quantile regression. Anesthesiology. 2010;112(3):688-695.

18. Symeonidi M, Panagiotou I, Tsilika E, Roumeliotou A, Galanos A, Mystakidou K. Factors Affecting Opioid Treatment in Cancer Patients. J Pharm Pharm Sci. 2018;21(1):256. doi:10.18433/jpps29396

19. Naples JG, Gellad WF, Hanlon JT. Managing pain in older adults: The role of opioid analgesics. Clin Geriatr Med. 
2016;32(4):725-735.

20. Singh H, Banipal RPS, Singh B. Assessment of Adequacy of Pain Management and Analgesic Use in Patients With Advanced Cancer Using the Brief Pain Inventory and Pain Management Index Calculation. J Glob Oncol. 2016;3(3):235-241.

21. Carlson CL. Effectiveness of the World Health Organization cancer pain relief guidelines: an integrative review. J Pain Res. 2016:20.

22. Bandieri E, Romero M, Ripamonti CI, et al., Randomized Trial of Low-Dose Morphine Versus Weak Opioids in Moderate Cancer Pain. J Clin Oncol Off J Am Soc Clin Oncol. 2016;34(5):436-442.

23. Ahmedzai S, Brooks D. Transdermal fentanyl versus sustained-release oral morphine in cancer pain: preference, efficacy, and quality of life. The TTSFentanyl Comparative Trial Group. J Pain Symptom Manage. 1997;13(5):254261.

24. Rudowska J. Management of breakthrough pain due to cancer. Contemp Oncol. 2012;16(6):498-501.

25. Devulder J, Jacobs A, Richarz U, Wiggett $H$. Impact of opioid rescue medication for breakthrough pain on the efficacy and tolerability of long- acting opioids in patients with chronic non-malignant pain. BJA $\mathrm{Br} J$ Anaesth. 2009;103(4):576-585.

26. Yang Q, Xie D-R, Jiang Z-M, et al., Efficacy and adverse effects of transdermal fentanyl and sustainedrelease oral morphine in treating moderate-severe cancer pain in Chinese population: a systematic review and meta-analysis. J Exp Clin Cancer Res. 2010;29:67. doi:10.1186/1756-9966-29-67

27. Thapa N, Maharjan M, Xiong $\mathrm{Y}$, et al., Impact of cervical cancer on quality of life of women in Hubei, China. Sci Rep. 2018;8(1):11993.

28. Payne R, Mathias SD, Pasta DJ, Wanke LA, Williams R, Mahmoud R. Quality of life and cancer pain: satisfaction and side effects with transdermal fentanyl versus oral morphine. J Clin Oncol Off J Am Soc Clin Oncol. 1998;16(4):1588-1593.

29. Brush DE. Complications of Long-Term Opioid Therapy for Management of Chronic Pain: The Paradox of OpioidInduced Hyperalgesia. J Med Toxicol. 2012;8(4):387-392.

30. Velayudhan A, Bellingham G, MorleyForster P. Opioid-induced hyperalgesia. Contin Educ Anaesth Crit Care Pain. 2014;14(3):125-129. 